\title{
HOMEMADE SLOW-ACTION FERTILIZERS, AS AN ECONOMIC SOLUTION FOR ORGANIC FOOD PRODUCTION
}

\author{
Tomasz Ciesielczuk', Joanna Poluszyńska², Czesława Rosik-Dulewska³
}

1 Department of Land Protection, Opole University, Oleska Str. 22, 45-052 Opole, Poland, e-mail: tciesielczuk@uni. opole.pl

${ }^{2}$ Institute of Ceramics and Building Materials, Oświęcimska Str. 21, 45-641 Opole, Poland, e-mail:j.poluszynska@ icimb.pl

${ }^{3}$ Institute of Environmental Engineering of the Polish Academy of Sciences, Skłodowskiej-Curie Str. 34, 41-819 Zabrze, Poland, e-mail: czeslawa.rosik-dulewska@ipis.zabrze.pl

Received: 2016.12.05

Accepted: 2017.01.02

Published: 2017.03.01

\begin{abstract}
Organic plant cultivation, especially those intended for human consumption, poses new requirements for gardening. It is recommended to use organic slow-action fertilizers, which provide doses of nutrients essential for plants for a long time. Particularly valuable fertilizers are those that arise within the household, due to their high quality and the absence of costs associated with their purchase and transport. Organic matter contained in the food industry waste or arising in households, in the absence of contamination by other types of waste, can be used for self-production of organic fertilizer. The paper presents the results of testing organic fertilizers, which you can make yourself, destined for the cereal plants. The experimental fertilizers were made from coffee spent grounds (CSG) and ash from the thermal conversion of biomass (A), and the components limiting the amount of pests in the form of leaves and flowers of tansy (Tanacetum vulgare L.). The fertilizer can be used at the time of planting and sowing, because of the slow release of nutrients. Moreover, the addition of leaves and flowers of tansy helps to protect the seedling due to the content of essential oils. As a comparison, the horse manure and rabbit droppings fertilizers were used. Such fertilizers can be prepared independently, which leads not only to reducing the weight of biodegradable and mineral waste, but also provides the ability to generate financial savings of the household and promote organic gardening. Fertilizers made from a mixture of CSG and A support the implementation of good agricultural practice and sustainable development.
\end{abstract}

Keywords: fertilizer, coffee, biomass ash, tansy, manure, organic cultivation

\section{INTRODUCTION}

Soil improvement is a necessary procedure designed to provide essential nutrients to plants. Not only the occurrence of diseases, pests and drought, but also a shortage of nutrients in the soil can cause a loss in a crop. Because of the slow effect, it is particularly important to provide the nutrients in the form of organic or organic-mineral fertilizers. An organic matter derived from biodegradable waste is valuable, and cumulated in a landfill is a source of methane emissions into the air. In Poland the annual consumption of mineral fertilizers (NPKCa in pure component) is nearly 2 million $\mathrm{Mg}$, and almost 65 thousand $\mathrm{Mg}$ of pesticides [Statistical Yearbook of Agriculture $2015]$ is sold. In organic agriculture, pests can cause significant losses of seedlings and the use of commercially available synthetic pesticides is prohibited due to the human health issues and environmental pollution. Thus, fertilizers in addition to the providing the necessary nutrients function, should also reduce the losses caused by fungal and bacterial diseases as well as pests.

The most useful organic fertilizers are: manure, slurry, liquid manure, green fertilizers, waste from biogas production and composts. Biodegradable waste can be disposed in various ways, but 
rarely can be used in unprocessed form [Kazimierowicz 2014]. Such fertilizers (especially composts from municipal waste and manure), may apply to the soil a significant amount of metal ion impurities, which can be absorbed by plants. Poor quality of this type of materials is caused by the addition of highly contaminated components such e.g. waste from sweeping the streets [Adamiec et al. 2016; Fekri and Kaveh 2013]. Another factor is the cost associated with the time needed to obtain compost and the need to periodically drafting of heaps. The use of organic-mineral fertilizers in the form of pellets simplify the use of fertilizers in a gardening production as well as in private household gardens and potted plants. However, to achieve effective fertilization process, the protection against diseases and pests has to be provided, through the use of a natural additive - biocide. The fertilizer, which uses a combination of mineral material (A) with the organic phase of post-extraction coffee waste (CSG) and the dried leaves or flowers of tansy (Tanacetum vulgare L.), is a solution that can fundamentally contribute to balanced fertilization and crop protection, also by unqualified persons. Tansy contains essential oils, having not only bacteriostatic function, but which may also have neurotoxic impact (due to the content of a and b-thujone) on animal organisms, including soil zoo-pathogens [Moricz et al. 2015]. As a mineral biogens source the ashes formed after combustion of biomass can be applied. At present, the biomass is widely used as an energy source, which is associated with the formation of significant quantities of ash. Polish energy policy for the next years assumes a steady increase in the share of energy produced from renewable sources, which will also increase the amount of ash, including the burning of straw. The agricultural sector in Poland produces about 200-300 million Mg of biomass, including about 25 million $\mathrm{Mg}$ of straw [BzdawkaPiątkowska 2007; Kwaśniewski 2008]. We can get about 740 thousand $\mathrm{Mg}$ of ash from burning it, which can be used in the production of fertilizers. For the purposes of organic agriculture on small scale, produced ash should be limited to biomass boilers with low power (up to 30-50kW), in which the fuel has good quality, because the ash from power boilers can contain significant amounts of PAHs, which in the case of application ash into soil migrate in the food chain [Poluszyńska 2013].

Similar attempts were made in relation to the ashes from coal-fired furnaces [Antonkiewicz 2009, Rosik-Dulewska et al. 2013, Roszyk et al.
2004]. The use of nutrients from the ashes derived from the combustion of biomass has already been known for many years, but right now it is essential to provide a thorough inspection of ash derived from burning energy plants fertilized with sewage or sewage sludge [Bielicka et al. 2007]. The essence of sustainable crop production is the use of mineral and organic fertilization integrated with plant protection based on ingredients of natural origin. The optimal solution would be fertilizer with repellent, which can be used at the time of sowing, planting or replanting, and also can be prepared independently in the household. For many years, the work continued on defining the impact of using organic waste as a fertilizer (sewage sludge, food industry waste) on the quality of soils and obtained crops, also in terms of the use of granular fertilizers. However, the combination of repellent and fertilizer features is found only in the case of mineral fertilizers commercially available in the form of sticks to use in amateur crops, and is based on the conventional pesticides, slowly releasing into the soil solution [Barbera et al. 2013, Ociepa-Kubicka and Pachura 2013, Rosik-Dulewska et al. 2009; Rosik-Dulewska et al. 2013]. The fertilizers with natural repellent function proposed here can be used even in the organic vegetable cultivation, and in addition they are safe for people applying them and are produced on one's own which reduces the costs associated with the purchase of fertilizers. A similar solution, but for which professional isolation process of bacteria adversely affecting the growth of pathogenic fungi, was proposed for the cultivation of pepper [Wu et al. 2015].

\section{MATERIALS AND METHODS}

For the production of granulated fertilizers, the post-extraction waste of coffee (CSG) was used as a result of coffee beverage preparation, dried in the sun and dried again to constant weight at $105{ }^{\circ} \mathrm{C}$. The binder was gelatin commercially available. The gelatin solution was performed by soaking 10 grams of gelatin in cold deionized water, and then the obtained gel was transferred into boiling deionized water and boiled. As a mineral supplement the ash was used, derived from biomass combustion of burning oak wood with bark in the form of particles, at 600 ${ }^{\circ} \mathrm{C}$ for 3 hours in a muffle furnace, and then re-combusted at this temperature for 1 hour [Ciesielczuk et al. 2015]. The obtained ash (A), was sieved through a mesh of $2 \mathrm{~mm}$, and then dried to constant weight. 
The composition of various types of fertilizers made on the basis of CSG and A are shown in Table 1. Fertilizer K10 was made using the proportion of the mass given by Ciesielczuk et al. (2015), but a granular form was used, without the collagen integument. As fertilizer with deacidification properties the type K20 was selected, with a larger share of biomass ash.

\section{BOTANIC CHARACTERISTIC}

Tansy (Tanacetum vulgare L.) occurs throughout the country and is a plant with a characteristically unpleasant odour. Its flowers contain essential oils, including thujone, which due to its properties has been used for the treatment of parasitic diseases. These properties mean that it has also been used in folk medicine. The plant spreads rapidly by rhizomes and seeds. In autumn and winter, it is a source of food for wintering bird life in Poland

\section{PREPARATION OF ORGANIC ADDITIVES}

The leaves and flowers of tansy (Tanacetum vulgare L.) were collected carefully so the roots and plants rhizomes were not destroyed. After transportation to the laboratory, the plants were cut and dried on filter paper at room temperature. Leaves and flowers of tansy were dried separately, turning from time to time in order to avoid mould growth. The dried plant parts were milled, sieved through a $1 \mathrm{~mm}$ mesh and stored in the dark at a temperature of $<20^{\circ} \mathrm{C}$.

\section{THE METHOD OF MAKING FERTILIZER GRANULES}

CSG, dried to constant weight, were mixed thoroughly with the ash A in a 9:1 proportion (Ta- ble 1) and with the additive typical for each type of fertilizer - tansy flowers or leaves. Then a solution of gelatin was added, cooled to room temperature. After mixing the components precisely, the mass was pressed through a die with a mesh diameter of $2 \mathrm{~mm}$. The obtained pellets were dried at room temperature. Horse manure pellets were made the granulator with a die having a mesh diameter of 2 $\mathrm{mm}$ and dried at room temperature. Rabbit droppings, obtained in the form of natural pellets of a $7-8 \mathrm{~mm}$ diameter, were only dried in a room temperature without converting them in a granulator.

In the tested fertilizers it was determined: the organic matter content by gravimetric method after ignition at $600{ }^{\circ} \mathrm{C}$ for 3 hours. The $\mathrm{pH}$ value was determined with $\mathrm{H}_{2} \mathrm{O}$ and $1 \mathrm{M} \mathrm{KCl}$. Electrical conductivity (EC) and $\mathrm{pH}$ were determined by electrometric methods. The organic carbon content was determined by TOC Cube analyzer with a infrared detection function from Elementar. The nitrogen content was determined by Kjeldahl method. The phosphorus content was determined by titration after mineralization with sulfuric acid. The contents of sodium, potassium and calcium were determined in the samples after mineralization by the FES method using a BWB XP instrument. The contents of magnesium and heavy metals were determined by atomic absorption spectroscopy using a ICE Thermo 3500 after microwave mineralization with aqua regia in the Mars- $\mathrm{X}$ device.

\section{RESULTS AND DISCUSSION}

All tested types of fertilizers were characterized by a dark brown-black color, and the obtained results of analyzed types: HM, RD, K10, K20, KWL and KWK were shown in Table 2.

The tested fertilizers are a light material (tab.2), which simplifies transport and creates no difficulty during fertilization. The granular

Table 1. Mass proportion of components in fertilizer granules

\begin{tabular}{|c|c|c|c|c|c|c|}
\hline & $\begin{array}{c}\text { Coffee spent } \\
\text { grounds (CSG) }\end{array}$ & $\begin{array}{c}\text { Biomass ash } \\
(\mathrm{A})\end{array}$ & $\begin{array}{c}\text { Horse } \\
\text { manure } \\
(\mathrm{HM})\end{array}$ & $\begin{array}{c}\text { Rabbit } \\
\text { droppings } \\
(\mathrm{RD})\end{array}$ & $\begin{array}{c}\text { Tansy leaves } \\
(\mathrm{TL})\end{array}$ & $\begin{array}{c}\text { Tansy } \\
\text { flowers } \\
(\mathrm{TF})\end{array}$ \\
\hline $\mathrm{HM}$ & 0 & 0 & 10 & 0 & 0 & 0 \\
\hline $\mathrm{RD}$ & 0 & 0 & 0 & 10 & 0 & 0 \\
\hline $\mathrm{K} 10$ & 9 & 1 & 0 & 0 & 0 & 0 \\
\hline K20 & 8 & 2 & 0 & 1 & 0 & 0 \\
\hline KWL & 8 & 1 & 0 & 0 & 1 & 0 \\
\hline KWK & 8 & 1 & 0 & 0 & 0 & 1 \\
\hline
\end{tabular}


form of fertilizers allows to avoid losses resulting from dusting. The $\mathrm{pH}$ of the proposed fertilizer is neutral or slightly alkaline (types HM and K20), which is advantageous in case of deacidifying and stabilizing effect the soil $\mathrm{pH}$. The electrical conductivity indicates that the amount of easily leached salts is the highest in HM type and such a fertilizer can cause a temporary salinity of the soil solution, which may adversely affect plant growth. However, the EC values found in manure may be much higher and reach almost $18 \mathrm{mS} / \mathrm{cm}$ [Fekri and Kaveh 2013]. In other types of fertilizers EC value does not exceed $3.5 \mathrm{mS} / \mathrm{cm}$, which guarantees no negative impact on young seedlings of most crops [Mazur et al. 2013]. Organic matter content (defined as loss of ignition), was very high in the examined fertilizers (well-nigh 67\% for $\mathrm{HM}$, and more than $90 \%$ for RD and $\mathrm{K} 10$ ), which is particularly important for fertilizing sandy soils where the water retention time is small, and the organic matter contained in fertilizers increases the water capacity. The content of organic matter in good composts is lower and rarely exceed 50\% s.m. [Meller et al. 2015; Poluszyńska et al. 2012]. The fat content in the applied fertilizers involving CSG can increase water retention in the soil, which was confirmed by field studies using wastewater from olive oil mill [Barbera et al. 2013]. A big advantage is also high organic carbon content (over 32\%), which is comparable to the amount in manure, and much higher than that found in composts [Poluszyńska et al. 2012; Poulsen et al. 2012]. Fertilizers containing tansy tissues are characterized by high and even organic carbon content (approximately $40 \% \mathrm{dm}$ ). Poor soils (for which tested fertilizers are dedicated) used in the gardening production allow to reduce manufacturing costs, and the proposed organic fertilizers help to reduce the consumption of nonrenewable peat resources. The gelatin, used in the fertilizers production process, plays a key role not only in the process of slowing down the leaching of biogens into the soil solution, but is also the source of organic material and finally nitrogen in the form available for plants. Organic matter from $\mathrm{HM}, \mathrm{RD}, \mathrm{CSG}, \mathrm{WL}$, WK and gelatin, slowly mineralizating, releases biogens into the soil solution in a sustainable way which prevents over-fertilizing and significantly extends the fertilizer effect. As a result, the expected duration of a dose of fertilizer is $1.5-2.5$ months. Using components so rich in organic matter, not only maintains but also increases soil fertility [Piwowar 2013].

Nitrogen content is high (2.69-3.83\%) and meets the requirements of the Regulation of the Minister of Agriculture and Rural Development on the implementation of certain provisions of the legislation on fertilizers and fertilization [RMARD

Table 2. Basic characteristics of investigated fertilizers granules and comparison with data obtained to law requirements for organic fertilizers

\begin{tabular}{|c|c|c|c|c|c|c|c|}
\hline & $\mathrm{HM}$ & RD & K10 & K20 & KWL & KWK & RMARD 236 \\
\hline $\begin{array}{c}\text { Bulk density } \\
{\left[\mathrm{g} / \mathrm{dm}^{3}\right]}\end{array}$ & 326.0 & 245.7 & 422.6 & 440.1 & 417.8 & 419.8 & - \\
\hline $\mathrm{pH}_{\mathrm{H} 2 \mathrm{O}}$ & $8.23-8.25$ & $7.19-7.23$ & $7.04-7.07$ & $8.97-9.22$ & $7.63-7.65$ & $7.60-7.62$ & - \\
\hline $\mathrm{pH}_{\mathrm{KCl}}$ & $8.11-8.18$ & $6.18-6.21$ & $6.97-7.07$ & $8.85-8.95$ & $7.58-7.61$ & $7.48-7.51$ & - \\
\hline $\mathrm{EC}[\mathrm{mS} / \mathrm{cm}]$ & $\begin{array}{c}7.34 \\
(0.08)\end{array}$ & $\begin{array}{c}1.61 \\
(0.01)\end{array}$ & $\begin{array}{c}2.42 \\
(0.05)\end{array}$ & $\begin{array}{c}3.42 \\
(0.05)\end{array}$ & $\begin{array}{c}3.19 \\
(0.04)\end{array}$ & $\begin{array}{c}2.66 \\
(0.01)\end{array}$ & - \\
\hline $\begin{array}{c}\text { Organic matter } \\
{[\%]}\end{array}$ & $\begin{array}{l}66.8 \\
(0.6)\end{array}$ & $92.9(0.2)$ & $91.6(0.4)$ & $80.7(0.2)$ & $\begin{array}{l}89.3 \\
(0.06)\end{array}$ & $89.5(0.2)$ & $>30$ \\
\hline TOC [\%] & $\begin{array}{l}32.3 \\
(0.3)\end{array}$ & $\begin{array}{l}38.3 \\
(0.3)\end{array}$ & $\begin{array}{c}46.6 \\
(3.12)\end{array}$ & $\begin{array}{l}37.1 \\
(0.9)\end{array}$ & $\begin{array}{c}41.2 \\
(0.11)\end{array}$ & $\begin{array}{c}39.9 \\
(0.05)\end{array}$ & - \\
\hline $\begin{array}{c}\text { Kiejdahl } \\
\text { nitrogen [\%] }\end{array}$ & $\begin{array}{l}3.60 \\
(0.11)\end{array}$ & $\begin{array}{c}2.69 \\
(0.26)\end{array}$ & $\begin{array}{c}3.36 \\
(0.38)\end{array}$ & $\begin{array}{c}3.06 \\
(0.23)\end{array}$ & $\begin{array}{c}3.83 \\
(0.18)\end{array}$ & $\begin{array}{c}3.75 \\
(0.29)\end{array}$ & $>0.3$ \\
\hline $\mathrm{C} / \mathrm{N}$ & 8.9 & 14.2 & 13.9 & 12.1 & 10.8 & 10.6 & - \\
\hline $\begin{array}{c}\mathrm{CaO} \\
{[\mathrm{g} / \mathrm{kg} \mathrm{dm}]}\end{array}$ & 2.51 & 0.42 & $\begin{array}{c}14.9 \\
(0.36)\end{array}$ & $\begin{array}{c}47.2 \\
(0.62)\end{array}$ & 28.0 & 27.6 & - \\
\hline $\begin{array}{c}\mathrm{MgO} \\
{[\mathrm{g} / \mathrm{kg} \mathrm{dm}]}\end{array}$ & 7.65 & 1.79 & $\begin{array}{l}7.76 \\
(0.06)\end{array}$ & $\begin{array}{c}11.1 \\
(1.38)\end{array}$ & 4.45 & 4.43 & - \\
\hline $\begin{array}{c}\mathrm{Na}_{2} \mathrm{O} \\
{[\mathrm{g} / \mathrm{kg} \mathrm{dm}]}\end{array}$ & 5.06 & 0.55 & $\begin{array}{c}0.37 \\
(0.04)\end{array}$ & $\begin{array}{c}0.58 \\
(0.05)\end{array}$ & 0.49 & 0.53 & - \\
\hline $\begin{array}{c}\mathrm{K}_{2} \mathrm{O} \\
{[\mathrm{g} / \mathrm{kg} \mathrm{dm}]}\end{array}$ & 27.0 & 3.57 & $\begin{array}{l}9.97 \\
(0.08)\end{array}$ & $\begin{array}{l}20.2 \\
(0.18)\end{array}$ & 16.5 & 16.2 & $>2.0$ \\
\hline $\begin{array}{c}\mathrm{P}_{2} \mathrm{O}_{5} \\
{[\mathrm{~g} / \mathrm{kg} \mathrm{dm}]}\end{array}$ & 22.9 & 12.2 & $\begin{array}{l}7.35 \\
(0.09)\end{array}$ & $\begin{array}{l}7.91 \\
(0.27)\end{array}$ & 7.90 & 7.16 & $>2.0$ \\
\hline
\end{tabular}

$\mathrm{SD}$ value in the brackets 
236]. Kjeldahl nitrogen content is similar in all 6 series of examined fertilizers (the lowest in the K20 because of an essential share of biomass ash). Good quality compost contains a similar amount of nitrogen to organic fertilizers examined here, but its production is extremely slow, and composts coming from professional composting plants may contain higher levels of heavy metals which eliminates them from gardening practice [Ciesielczuk et al. 2011]. Furthermore, composts produced in private farms may contain more than three times lower amount of nitrogen (about $0.9-1.0 \%$ ) due to the addition of ash from wood-fired boilers or fireplaces [Kurola et al. 2011]. The presence of this element in the organic form ensures its even and slow release into the soil solution, which is not only advantageous to the long-term fertilizing process (preventing chlorosis of leaves), but also prevents it from leaching into groundwater [Wójcik et al. 2014]. In opposition there are encapsulated fertilizers with controlled release of biogens, which especially in the first period after their application, release too many ions of nitrogen to the soil solution [Golcz and Komosa 2006].

The calcium content (Table 2) is the highest in the K20 type, providing proper deacidification of the cultivation ground, and the lowest in the $\mathrm{RD}$ manure (only $0.42 \mathrm{~g} / \mathrm{kg} \mathrm{sm}$.), which is a disadvantageous not only in the case of stabilizing the $\mathrm{pH}$, but also plant nutrition. The main source of calcium in the K10, K20, KWL and KWK fertilizers is the biomass ash, which mixed with CSG and bound by gelatin will be relatively resistant to quick leaching, which will favor the stabilization of the soil $\mathrm{pH}$, contributing to the reduction of the heavy metals availability to crops, but also the activity of exchangeable aluminum [Ciba et al. 2007, Hermann and HarasimowiczHermann 2005]. Liming is one of the most important treatments allowing to maintain a proper $\mathrm{pH}$ and soil structure which helps obtaining high crops [Arvidsson and Lundkvist 2003; Krzysztoforski 2010]. In case of using only the ash from biomass as a source of calcium, the humus layer of soil is too alkalized (biomass ash $\mathrm{pH}$ is about 10.95-13.00) and the ash components are too quickly leached into the soil profile [Poluszyńska and Ślęzak 2015]. The pH stabilization process is an important element of cultivation due to the reduction of heavy metals absorption, however, too rapid change in soil $\mathrm{pH}$ (e.g. through the use of the biomass ash or lime fertilizer in the form of oxide), affects the microflora adversely so that it is not recommended for organic farming.
In the analyzed samples with the mixture of A and CSG fertilizers, the source of magnesium is biomass ash and, to a lesser extent, organic matter. Ions $\mathrm{Mg}^{2+}$ are particularly important because of the essential role of this element in the construction of chlorophyll and also its susceptibility to leaching [Gransee and Fuhrs 2013]. Pellets stabilized by gelatin provides a slow release of magnesium to the soil solution which prevents losses caused by leaching into the soil profile.

The potassium content is high in all the tested types of fertilizer, except RD $(3.57 \mathrm{~g} / \mathrm{kg}$ of $\mathrm{dm})$. Most of this element $-27 \mathrm{~g} \mathrm{~K}_{2} \mathrm{O} / \mathrm{kg} \mathrm{dm}$ was found in the HM fertilizer and $\mathrm{K} 20$ - here due to the high content of A. In all examined series of fertilizer, potassium content corresponds to legal requirements considering organic fertilizers.

The phosphorus content is similar in experimental fertilizers series, however, the highest (as potassium) in HM manure. Bioavailability of phosphorus from natural fertilizers (e.g. manure) is high, while the phosphorus contained in the biomass ash is poorly soluble in water and, therefore, its bioavailability is limited. However, in case of fertilizers containing CSG, the content of organic phosphorus will significantly complement potential shortfall of this element [Demeyer et al. 2001]. The phosphorus content in the analyzed fertilizer granules meets the requirements of the Ordinance [RMARD 236].

The results of heavy metals content (Table 3 ), indicate that ash is the primary source of microelements. In particular, zinc, copper and iron are necessary (in relative high amounts) for plant metabolism [Kucharski and Jastrzębska 2005]. Their amount is medium and rest of investigated metals - low, so that there is no risk of soil and crops contamination by toxic elements $(\mathrm{Pb}, \mathrm{Ni}, \mathrm{Cr}, \mathrm{Cd}$ and $\mathrm{Hg}$ ), even in the series with the highest share of biomass ash (K20). Therefore, there is a possibility of using these granules in vegetables crops intended for direct consumption. The Regulation of the Minister of Agriculture and Rural Development on the implementation of certain provisions of the legislation on fertilizers and fertilization [RMARD 236] clarify the maximum content of nickel, cadmium, chromium, lead and mercury for organic fertilizers. Recorded concentrations do not even come close to acceptable levels contained in the Regulation. Compatibility of tested fertilizers (except for HM with exceeded levels of zinc and copper, and K20, with exceeded zinc level), with the requirements of organic crops should be underlined. 
Table 3. Semi total content of heavy metals investigated in granulated fertilizers and composts and maximum levels for organic fertilizers and organic farming $[\mathrm{mg} / \mathrm{kg} \mathrm{dm}]$

\begin{tabular}{|c|c|c|c|c|c|c|c|c|c|}
\hline & $\mathrm{HM}$ & $\mathrm{RD}$ & $\mathrm{K} 10$ & $\mathrm{~K} 20$ & $\mathrm{KWL}$ & $\mathrm{KWK}$ & $\begin{array}{c}\text { Compost } \\
\text { [Ciesielczuk } \\
\text { 2011] }\end{array}$ & RMARD 236 & $\begin{array}{c}\text { CIR } \\
\text { (EU) No } \\
354 / 2014\end{array}$ \\
\hline $\mathrm{Zn}$ & 297.6 & 68.1 & 79.1 & 232.4 & 147.0 & 145.1 & $277-1756$ & - & 200 \\
\hline $\mathrm{Cu}$ & 122.9 & 12.3 & 15.1 & 31.9 & 26.09 & 25.54 & $36.3-283$ & - & 70 \\
\hline $\mathrm{Ni}$ & 20.44 & 7.21 & 3.13 & 11.4 & 5.67 & 3.97 & $11.3-217$ & 60 & 25 \\
\hline $\mathrm{Pb}$ & 3.94 & $<0.05$ & 1.58 & 3.14 & 1.59 & 1.22 & $24.6-545$ & 140 & 45 \\
\hline $\mathrm{Cd}$ & 0.016 & $<0.012$ & 0.13 & 0.389 & $<0.012$ & $<0.012$ & $<0.5-4.28$ & 5 & 0.7 \\
\hline $\mathrm{Cr}$ & $<0.1$ & $<0.1$ & $<0.1$ & $<0.1$ & $<0.1$ & $<0.1$ & $22.4-79.8$ & 100 & $\begin{array}{c}\mathrm{Cr}_{\text {TOT }} \\
\mathrm{Cr}^{\mathrm{V}}(0.0)\end{array}$ \\
\hline $\mathrm{Mn}$ & 398.8 & 72.1 & 447 & 1297 & 856.2 & 864.1 & - & - & - \\
\hline $\mathrm{Fe}$ & 2724 & 498.1 & 126 & 341.5 & 209.6 & 163.1 & - & - & - \\
\hline $\mathrm{Hg}$ & 0.1015 & 0.0444 & 0.0052 & 0.0114 & 0.0055 & 0.0058 & & 2 & 0.4 \\
\hline
\end{tabular}

Organic fertilizers such as manure can contain, depending on the origin, increased amounts of these elements (including horse manure HM studied here), which may pose a potential threat to crops [Fekri and Kaveh 2013; Tella et al. 2013]. Although the horse manure examined here has slightly higher concentrations of zinc, copper, nickel and lead, it still fully meets the requirements of the law, but it is not possible to use it in organic crops. This validates the use of analyzed granulated fertilizers (K10, KWL and KWK) based on materials almost free from contamination with metal ions. It is assumed that the amount of bioavailable forms of metals in the tested fertilizers will comprise up to $40-50 \%$ of their total content, which must be confirmed or ruled out with specific tests [Rosik-Dulewska et al. 2008; Rosik-Dulewska et al. 2013]. Moreover, the addition of a significant amount $(10 \% \mathrm{~m} / \mathrm{m})$ of dried leaves or flowers of tansy, will have a positive impact on plant growth and development due to their fungicidal and insecticidal effect [Akpulat et al. 2004].

Selective collection of biodegradable waste, even carried out with particular care, does not always give an expected results. Well-sorted "bio" wastes are mixed with a waste from various sources in a composting plant, and the level of contamination by other groups of waste is still significant. The final result is bad - compost contaminated with huge amounts of plastic, glass cullet and heavy metals. Such a compost is often eliminated from fertilizer use as off-specification [Boruszko 2011; Poluszyńska et al. 2012]. Composts produced on the farm may be contaminated with the feces of animals (dogs, cats, martens) penetrating the heap of compost so that there is a probability of contaminating the compost with an- imal endoparasites (eg. Toxocara spp.), which can retain invasive activity up to 10 years [Kłapeć and Cholewa 2012]. On the other hand, biodegradable CSG waste managed without composting, is not exposed to pollution and their quality allows to use them in organic crops. CSG and A waste, generated in the household, are available for free and have high quality. The only costs of fertilizers produced in the house is the energy for heating the water to form a solution of the gelatin and the gelatin itself. To avoid those costs, a different binder can be used - rice starch, remaining in water after boiling the rice [Ciesielczuk et al. 2016].

\section{CONCLUSION}

Granulated fertilizers, extremely popular in amateur and professional gardening production, usually occur in the leading gardening companies products and have a relatively high price. An important alternative would be the ability to produce them on one's own or in small family businesses operating on the local market. The significant parts of a fertilizer in the granulation process are problematic and easily decaying coffee spent grounds (CSG) Production of granulated fertilizers made on the basis of CSG and ash from the thermal conversion of biomass and plant additives, not only allows to reduce the volume of waste going to landfill, but also can be a factor boosting the productivity of soils. These fertilizers with a high content of organic nitrogen and potassium, calcium, and organic matter decompose slowly, which is important from the point of view of availability of nutrients. Nitrogen occurring in the examined fertilizers only in the organic form allows to use the fertilizers at 
the time of sowing or planting, and its slow release in plant-available forms prevents the loss of this element. The slow decay of granules extends the operating time of the fertilizer that releases biogens gradually, in line with the principles of sustainable development. Lower heavy metal content than this occurring in composts and manure indicates a high quality of tested fertilizers which allows their use in organic crop. These fertilizers used in professional or amateur gardening production, can cause a significant reduction in cultivation costs, due to the possibility of fertilizing at the time of sowing or planting. This is particularly important for the plant production in containers when the use of poor mineral soil can contribute to lower the manufacturing costs and reduce pressure on the environment by reducing the exploitation of peat - a material commonly used in the production of organic soils. Literature reports indicate, that the addition of dried leaves and flowers of tansy should have a positive impact on the growth of crops, through bacteriostatic, fungicidal and insecticidal effect. This is particularly relevant for organic farming, which cannot use the traditional pesticides.

\section{REFERENCES}

1. Adamiec E., Jarosz-Krzemińska E., Wieszała R. 2016. Heavy metals from non-exhaust vehicle emissions in urban and motorway road dusts. Environ. Monit. Assess. 188: 369, DOI 10.1007/ s10661-016-5377-1.

2. Akpulat H.A., TepeB., Sokmen A., Daferera D., Polissiou M. 2005. Composition of the essential oils of Tanacetumargyrophyllum (C. Koch) Tvzel. var. argyrophyllum and Tanacetum parthenium (L.) Schultz Bip. (Asteraceae) from Turkey. Biochemical Systematics and Ecology 33, 511-516.

3. Antonkiewicz j. 2009. Wykorzystanie popiołów paleniskowych do wiązania metali ciężkich występujących w glebie. Ochrona Środowiska i Zasobów Naturalnych 41, 398-405.

4. Arvidsson H., Lundkvist H. 2003. Effects of crushed wood ash on soil chemistry in young Norway spruce stands. For. Ecol. Manage. 176, 121-132.

5. Barbera A.C., Maucieria C., Cavallarob V., Ioppoloa A., Spagna G. 2013. Effects of spreading olive mill wastewater on soil properties and crops, a review. Agricultural Water Management 119, 43-53. http://dx.doi.org/10.1016/j.agwat.2012.12.009

6. Bielicka A., Bojanowska I., Krupa A., Schuetz P., Leszczyński J. 2007. Biomasa - produkt II stopnia oczyszczania ścieków jako źródło energii odnawialnej. Ochrona Środowiska i Zasobów Naturalnych 31, 296-301.

7. Boruszko D. 2011. Badania i ocena wartości nawozowej kompostów i wermikompostów. Annual Set The Environment Protection 13, 1417-1428.

8. Bzdawka-Piątkowska K. 2007. Stan obecny i perspektywy rozwoju energetyki odnawialnej w Polsce. Ochrona Środowiska i Zasobów Naturalnych 33, 20-26.

9. Ciesielczuk T., Rosik-Dulewska Cz., Karwaczyńska U. 2011. Komposty z odpadów jako potencjalne źródło substancji organicznej i biogenów w produkcji roślinnej. (w) Kompostowanie i mechaniczno-biologiczne przetwarzanie odpadów (red.) G. Siemiątkowski 108-116 Opole 2011.

10. Ciesielczuk T., Rosik-Dulewska Cz., Poluszyńska J., Polis K. 2016. Naturalne spoiwa kostek nawozowych jako element zrównoważonej uprawy roślin. Proceedings of Ecopole 10(1), 111-119. DOI: $10.2429 /$ proc.2016.10(1)013

11. Ciesielczuk T., Rosik-Dulewska Cz., Wiśniewska E. 2015. Possibilities of coffee spent ground use as a slow action organo-mineral fertilizer. Rocz. Ochr. Środ. 17, 422-437. http://ros.edu.pl/images/ roczniki/2015/026_ROS_V17_R2015.pdf.

12. Ciba J., Skwira M., Zołotajkin M. 2007. Wpływ wybranych substancji chemicznych na zawartość glinu wymiennego i pH gleb leśnych - przegląd literaturowy. Ochrona Środowiska i Zasobów Naturalnych 31, 63-67.

13. CIR(EU) No 354/2014. Commission Implementing Regulation (EU) No 354/2014 of 8 April 2014 amending and correcting Regulation (EC) No 889/2008 laying down detailed rules for the implementation of Council Regulation (EC) No $834 / 2007$ on organic production and labelling of organic products with regard to organic production, labelling and control

14. Demeyer A., Voundi Nkana J.C., Verloo M.G. 2001. Characteristics of wood ash and influence on soil properties and nutrient uptake: on overview. Bioresource Technol. 77, 287-295.

15. Fekri M., Kaveh S. 2013. Heavy metal accumulation in soil after application of organic wastes. Arab J Geosci. 6:463-467 DOI 10.1007/ s12517-011-0328-1

16. Golcz A., Komosa A. 2006. Uwalnianie się azotu, fosforu i potasu z nawozu wolnodziałającego osmocote plus w uprawie papryki (Capsicum annuum L.) Acta Agrophysica 7(3), 567-576.

17. Gransee A., Fuhrs H. 2013. Magnesium mobility in soils as a challenge for soil and plant analysis, magnesium fertilization and root uptake under adverse growth conditions. Plant Soil 368: 5-21. DOI 10.1007/s11104-012-1567-y 
18. Hermann J., Harasimowicz-Hermann G. 2005. Przydatność popiołów ze spalania biomasy do stosowania w rolnictwie i rekultywacji gruntów. Inżynieria Ekologiczna 12, 195-196.

19. Kazimierowicz J. 2014. Organic waste used in agricultural biogas plants. Journal of Ecological Engineering 15(2), 88-92. DOI: $10.12911 / 22998993.1094983$

20. Kłapeć T, Cholewa A. 2012. Zagrożenia dla zdrowia związane ze stosowaniem nawozow organicznych i organiczno-mineralnych. Med Og Nauk Zdr. 18(2), 131-136.

21. Kucharski J., Jastrzębska E. 2005. Liczebność drobnoustrojów i właściwości fizyko-chemiczne gleby zanieczyszczonej popiołem drzewnym. J. Elementol. 10(3), 513-525.

22. Krzysztoforski M. 2010. Rolnictwo zrównoważone. PWN Warszawa pp.32

23. Kurola J.M., Arnold M., Kontro M.H., Talves M., Romantschuk M. 2011. Wood ash for application in municipal biowaste composting. Bioresource Technology 102, 5214-5220.

24. Kwaśniewski D. 2008. Ocena produkcji i potencjalnych możliwości wykorzystania słomy do celów grzewczych na przykładzie powiatu żywieckiego. Inżynieria Rolnicza 6, 113-119.

25. Ociepa-Kubicka A., Pachura P. 2013. Wykorzystanie osadów ściekowych i kompostu w nawożeniu roślin energetycznych na przykładzie miskanta i ślazowca. Annual Set The Environment Protection 15, 2267-2278.

26. Mazur Z., Radziemska M., Tomaszewska Z., Świątkowski Ł. 2013. Effect of sodium chloride salinization on the seed germination of selected vegetable plants. Scientific Review - Engineering and Environmental Sciences 62, 444-453.

27. Meller E., Niedźwiecki E., Rogalska P., Jarnuszewski G., Wilczyński D. 2015. Fertiliser value and trace element content of composts produced from different wastes. Journal of Ecological Engineering 16(4), 154-160. DOI: 10.12911/22998993/59365

28. Moricz A.M., Häbe T.T., Böszörményi A., Ott P.G., Morlock G.E. 2015. Tracking and identification of antibacterial components in theessential oil of Tanacetum vulgare L. by the combination ofhighperformance thin-layer chromatography with directbioautography and mass spectrometry. Journal of Chromatography A 1422, 310-317.

29. Piwowar A. 2013. Zarys problematyki nawożenia w zrównoważonym rozwoju rolnictwa w Polsce. Ekonomia i Środowisko 1(44), 143-155.

30. Poulsen P.H.B., Magid J., Luxhøi J., de Neergaard A. 2016. Effects of fertilization with urban and agricultural organic wastes in a field trial - Waste imprint on soil microbial activity. Soil Biology \& biochemistry 57, 794-802. doi:10.1016/j.soilbio.2012.02.031

31. Poluszyńska J. 2013. Ocena możliwości zanieczyszczenia środowiska glebowo-gruntowego wielopierścieniowymi węglowodorami aromatycznymi (WWA) zawartymi w popiołach lotnych pochodzących z kotłów energetycznych. Prace ICIMB 12, 60-77.

32. Poluszyńska J., Siemiątkowski G., Paciorkowski M. 2012. Charakterystyka kompostów z odpadów W świetle obowiązujących przepisów. Prace ICIMB 10, 231-246.

33. Poluszyńska J., Ślęzak E. 2015. Charakterystyka popiołów ze spalania biomasy i ocena możliwości ich wykorzystania w celach przyrodniczych. Prace ICIMB 23, 71-78.

34. RMARD 236. Regulation of Ministry of Agriculture and Rural Development No 236 from 21 of December 2009

35. Rosik-Dulewska Cz., Karwaczyńska U., Głowala K., Robak J. 2008. Elution of heavy metals from granulates produced from municipal sevage deposits and fly-ash of hard and brown in the aspect of recycling for fertilization purposes. Archives of Environment Protection 34( 2), 63-71.

36. Rosik-Dulewska Cz., Karwaczyńska U., Ciesielczuk T., Głowala K. 2009. Possibilities of non industrial re-usage of waste according to rules in of environment protection. Annual Set The Environment Protection 11, 863-874.

37. Rosik-Dulewska Cz., Karwaczyńska U., Ciesielczuk T. 2013. Metale ciężkie w granulatach popiołowo-osadowych wykorzystywanych do celów nawozowych. Przemysł Chemiczny 92/8,1520-1524.

38. Roszyk J., Nowosielski O., Komosa A. 2004. Przydatność ekstraktów z popiołu węgla brunatnego do nawożenia dolistnego kalafiora. Roczniki Akademii Rolniczej w Poznaniu - CCCLVI, 189-197.

39. Statistical Yearbook of Agriculture 2015. Central Statistical Office of Poland Warszawa 2016 pp. 456

40. Tella M., Doelsch E., Letourmy P., Chataing S., Cuoq F., Bravin M.N., Saint Macary H. 2013. Investigation of potentially toxic heavy metals in different organic wastes used to fertilize market garden crops. Waste Management 33, 184-192. http:// dx.doi.org/10.1016/j.wasman.2012.07.021

41. Wójcik P., Dyśko J., Kaniszewski S., Kowalczyk W., Nowak J. 2014. Zrównoważone nawożenie roślin ogrodniczych. pp. 64. Skierniewice 2014.

42. Wu Y., Zhao Ch., Farmer J., Sun J. 2015. Effects of bio-organic fertilizer on pepper growth and Fusarium wilt biocontrol. Scientia Horticulturae 193, 114-120. 